\title{
Gross nitrogen mineralization in pulse-crop rotations on the Northern Great Plains
}

\author{
Angela Bedard-Haughn • Louis-Pierre Comeau • \\ Amy Sangster
}

Received: 6 September 2012/ Accepted: 15 January 2013/Published online: 12 February 2013

(C) The Author(s) 2013. This article is published with open access at Springerlink.com

\begin{abstract}
Pulse crops represent an ever-increasing proportion of cropping systems in the Northern Great Plains. Previous studies have noted apparent benefits associated with pulse crop production that extend beyond the reduced need for $\mathrm{N}$ fertilizer in the year of production; these benefits have been attributed to the quality of pulse residues and their effects on $\mathrm{N}$ dynamics in subsequent years. This study used isotope dilution techniques to quantify the $\mathrm{N}$-cycling effects of pulse crops in the rotation. Gross $\mathrm{N}$ mineralization was measured over three growing seasons at two Agriculture and Agri-Food Canada research sites in Saskatchewan, Canada: Scott (four rotations; one with pulse crop) and Swift Current (three rotations; one with pulse crop). Gross nitrification and the relative contribution of nitrification vs. denitrification to $\mathrm{N}_{2} \mathrm{O}$ emissions were also measured. Across all dates and rotations, the average gross mineralization rate at Scott was $2.0 \pm 4.0 \mathrm{mg} \mathrm{NH}_{4}{ }^{+}-\mathrm{N} \mathrm{kg}^{-1}$ soil d ${ }^{-1}$ and at Swift Current was $1.4 \pm 3.9 \mathrm{mg} \mathrm{NH}{ }_{4}^{+}-\mathrm{N} \mathrm{kg}^{-1}$ soil
\end{abstract}

A. Bedard-Haughn $(\varangle) \cdot$ L.-P. Comeau · A. Sangster Department of Soil Science, University of Saskatchewan, 51 Campus Drive, Saskatoon, SK S7N 5A8, Canada e-mail: angela.bedard-haughn@usask.ca

L.-P. Comeau

School of Biological Science, University of Aberdeen, 23 St. Machar Drive, Aberdeen AB24 3UU, UK

\section{A. Sangster}

Perennia, 199 Innovation Drive, Bible Hill,

NS B6L 2H5, Canada $\mathrm{d}^{-1}$. At both sites, rates were highly variable across the growing season, but tended to be higher at anthesis than either pre-seeding or post-harvest. The only significant difference among rotations was at Swift Current, where the fertilized continuous wheat rotation had the highest gross mineralization rates (rotation average: $2.3 \mathrm{mg} \mathrm{NH}_{4}{ }^{+}-\mathrm{N} \mathrm{kg}^{-1}$ soil d ${ }^{-1}$ ). The lack of difference among most rotations was particularly notable given the differences in residue quantity among the crops. Ultimately, the lower quantity of residues produced by pulse crops appears to be offset by their higher quality.

Keywords Isotope dilution · Field pea $\cdot$ Lentil · Canola $\cdot$ Wheat $\cdot$ Chernozem

\section{Introduction}

Cropping systems in the Northern Great Plains have changed considerably since the beginning of agricultural production. Management modifications in these systems can have a profound effect on agro-ecosystem sustainability due to the scale of production; Saskatchewan alone has over 26 million ha of cropland in agricultural production (Statistics Canada 2006). In recent years, there has been an unprecedented shift to pulse and oilseed crops in dryland cropping regions (Miller and Holmes 2005); therefore, new interest has developed regarding the effects of these crops on soil 
processes, such as $\mathrm{N}$ cycling, and the effect of pulse crops on subsequent crops in rotation (Miller et al. 2006; Tanaka et al. 2007; Malhi et al. 2009). Depending on conditions, pulse crops such as field pea (Pisum sativum) can biologically fix up to $90 \%$ of their total plant $\mathrm{N}$ from the atmosphere (Walley et al. 2007). In contrast, canola $N$ requirements are commonly met through the use of synthetic $\mathrm{N}$ fertilizers at recommended application rates as high as $120 \mathrm{~kg} \mathrm{~N} \mathrm{ha}^{-1}$ for maximum seed yield (Gan et al. 2007). The reduced fertilizer $\mathrm{N}$ input for the pulse production year might not be the only benefit received from including pulse crops in rotation. Given that most of the fixed $\mathrm{N}$ is removed with the high-protein grain, yield benefits to crops following field pea have typically been attributed to $\mathrm{N}$ mineralized from field pea residue (Stevenson and van Kessel 1996; Beckie et al. 1997; Raun and Johnson 1999; Johnston et al. 2005; Miller and Holmes 2005). However, these N benefits are highly variable from year to year and are not consistent across all pulse crops (Walley et al. 2007).

Pulse $\mathrm{N}$ contribution is most commonly assessed by measuring soil $\mathrm{N}$ pools rather than processes. For example, Soon and Arshad (2004) reported spring available $\mathrm{N}$ concentrations were higher in rotations following legumes than cereal crops. Although net mineralization provides an index of plant available $\mathrm{N}$, it does little to explain the total amount of $\mathrm{N}$ cycling between organic matter and soil inorganic N (Robinson 2001). Gross rate measurements on the other hand, provide estimates of the total release of mineral $\mathrm{N}$ from a given pool. Gross processes of mineralization (ammonification), nitrification and consumption occur simultaneously in the soil, and their relative magnitudes will determine whether there is a net release of $\mathrm{N}$ into the soil (Recous et al. 1999; Murphy et al. 2003). However, even if net $\mathrm{N}$ accumulation is low, there will likely be plant-available $\mathrm{N}$ actively being produced throughout the season (Schimel and Bennett 2004). Estimates of gross $\mathrm{N}$ fluxes may help in predicting $\mathrm{N}$ availability in the soil, in particular when these measures of inorganic $\mathrm{N}$ production are repeated throughout the growing season, providing a better idea of when maximum mineralization occurs. Despite the potential to improve fertilizer timing, these methods are not commonly used on the Great Plains. A comprehensive review of gross $\mathrm{N}$ cycling studies included just three studies on gross $\mathrm{N}$ mineralization in semi-arid agricultural landscapes, and just one on gross nitrification (Booth et al. 2005).

Mineralization and nitrification, in addition to soil water content and temperature, also influence the rate of nitrous oxide $\left(\mathrm{N}_{2} \mathrm{O}\right)$ emissions in agricultural soils (Grant et al. 2004). Nitrous oxide is a potent greenhouse gas with a 100-year global warming potential 298 times that of carbon dioxide (IPCC 2007). In Canada, $\mathrm{N}_{2} \mathrm{O}$ emissions resulting from transformations of mineral $\mathrm{N}$ in agricultural soils make up the largest proportion of total $\mathrm{N}_{2} \mathrm{O}$ emissions (Rochette and McGinn 2008). However, $\mathrm{N}_{2} \mathrm{O}$ emissions from pulse crops may be lower than their fertilized counterparts (Lemke et al. 2002) likely due to decreased losses of $\mathrm{N}_{2} \mathrm{O}$ from fertilizer applications. Pulses may also affect the other factors contributing to emissions such as the quantity and quality of substrate (residue) supply for mineralization and nitrification of organic N.

Although $\mathrm{N}_{2} \mathrm{O}$ emissions have been attributed to several processes including nitrification, denitrification, coupled nitrification-denitrification, chemodenitrification, and nitrifier denitrification (Wrage et al. 2001), the two main processes believed to contribute to soil surface $\mathrm{N}_{2} \mathrm{O}$ flux in arable agriculture are denitrification and autotrophic nitrification (Pennock 2006). There are many reports of $\mathrm{N}_{2} \mathrm{O}$ emissions in the semi-arid Northern Great Plains (Corre et al. 1996; Malhi et al. 2006; Yates et al. 2006). However, there are few field experiments that report on the relative contributions of nitrification and denitrification to total $\mathrm{N}_{2} \mathrm{O}$ emissions (Bedard-Haughn et al. 2006; Ma et al. 2008). Stable isotope techniques have enabled differentiation and quantification of $\mathrm{N}_{2} \mathrm{O}$ produced during denitrification and nitrification (Baggs 2008).

A greater understanding of the effect of pulse crops (namely field pea and lentil) on $\mathrm{N}$ mineralization will help better delineate potential $\mathrm{N}$ benefits during the growing season and to succeeding crops. This study took advantage of established research plots in the Northern Great Plains that included cropping rotations both with and without pulse crops. This should allow a broader perspective on the longer-term effect of pulse crops in the rotation (Gan et al. 2010). The primary objective of this paper was to evaluate the effect of pulse crops in the rotation on gross mineralization rates, including the variability of these rates across the growing season. A secondary objective was to quantify the effect of pulse crops in the rotation on gross 
nitrification, including the relative contribution of nitrification related pathways to total $\mathrm{N}_{2} \mathrm{O}$ emissions.

\section{Materials and methods}

Site description

This study was carried out at Agriculture and AgriFood Canada (AAFC) research facilities in Saskatchewan, Canada: at AAFC Scott during the 2008, 2009, and 2010 growing seasons and at AAFC Swift Current during the 2009 and 2010 growing season. Table 1 summarizes the site characteristics and growing season climate (actual and 30-year normal) for both sites. Both sites had normal temperatures during the growing season in all 3 years, but there was substantial variation in precipitation among the study years. In 2008, Scott had three times greater-than-normal precipitation in April, above-normal precipitation in June, and normal precipitation levels in July; however, there was also lower-than-normal precipitation in May, August, and September. In 2009, both sites had below normal precipitation for the entire growing season, except for August. In contrast, in 2010, the entire season was well above normal precipitation for both sites, with the sole exception of July at Swift Current. Most notably, Scott received precipitation greater than its mean annual precipitation $(359 \mathrm{~mm})$ in the April-June period alone (Environment Canada 2012).

Table 1 Site characteristics and historical climate data (Environment Canada, 2012)

\begin{tabular}{|c|c|c|c|c|c|c|c|}
\hline & Site & & & & & & \\
\hline Site name & AAFC & & & & AAFC & Curren & \\
\hline Location & $52^{\circ} 23$ & $50^{\prime} \mathrm{W}$ & & & $50^{\circ} 12$ & ${ }^{\circ} 24^{\prime} \mathrm{W}$ & \\
\hline Ecoregion & Moist & grassla & & & Mixec & and & \\
\hline Soil type & Orthic & Brown & zem & & Orthic & n Chern & \\
\hline Texture & Loam & & & & Sandy & & \\
\hline $\mathrm{pH}^{\mathrm{a}}$ & 5.7 & & & & 6.4 & & \\
\hline $\operatorname{SOC}(\%)^{\mathrm{b}}$ & 3.4 & & & & 2.0 & & \\
\hline$D_{b}\left(g^{c} m^{-3}\right)^{c}$ & 1.2 & & & & 1.2 & & \\
\hline & 2008 & 2009 & 2010 & 30 -year mean & 2009 & 2010 & 30-year mean \\
\hline Mean daily ten & ire $\left({ }^{\circ} \mathrm{C}\right.$ & & & & & & \\
\hline April & 0.6 & 3.0 & 5.3 & 3.6 & 4.3 & 6.1 & 4.9 \\
\hline May & 10.4 & 8.7 & 8.8 & 10.9 & 9.9 & 7.9 & 11.1 \\
\hline June & 14.6 & 14.2 & 15.0 & 15.2 & 14.7 & 15.7 & 15.6 \\
\hline July & 16.8 & 15.8 & 16.6 & 17.0 & 16.9 & 17.1 & 18.1 \\
\hline August & 16.8 & 15.4 & 15.0 & 16.3 & 16.9 & 16.3 & 17.9 \\
\hline September & 10.9 & 14.3 & 9.3 & 10.4 & 16.4 & 10.6 & 11.8 \\
\hline Total precipita & ım) & & & & & & \\
\hline April & 72.4 & 16.6 & 108.9 & 23.6 & 14.2 & 44.3 & 22.3 \\
\hline May & 13.0 & 19.0 & 120.0 & 35.9 & 19.2 & 83.0 & 49.5 \\
\hline June & 87.0 & 30.4 & 147.0 & 62.5 & 30.3 & 121.5 & 66.0 \\
\hline July & 76.8 & 39.2 & 115.6 & 70.9 & 33.2 & 32.3 & 52.0 \\
\hline August & 20.8 & 57.4 & 40.0 & 43.1 & 52.0 & 85.3 & 39.9 \\
\hline September & 10.0 & 19.4 & 44.2 & 31.4 & 16.3 & 99.4 & 30.2 \\
\hline
\end{tabular}

Both sites were situated in long-term research plots at Agriculture and Agri-Food Canada (AAFC) Research Farms in Saskatchewan, Canada

\footnotetext{
a 1:2 $\mathrm{H}_{2} \mathrm{O}, 0-10 \mathrm{~cm}$

b Soil organic carbon, 0-10 cm

c Bulk density, 0-10 cm
} 
At Scott, two crop rotations were sampled in 2008: wheat-canola (Brassica napus-Triticum aestivum cv. Lillian; W-CNL), and wheat-field pea (Pisum sativumTriticum aestivum cv. Lillian; W-FP). In 2009 and 2010, continuous wheat without N fertilizer (W_0N) and continuous wheat with $\mathrm{N}$ fertilizer (W_WN) were added to the experiment to allow for inter-site comparisons with Swift Current (outlined below). The W-CNL and W-FP rotations were established in 1997; continuous wheat with $\mathrm{N}$ fertilizer was established in 2007 and without $\mathrm{N}$ was established in 2008. All plots were under no-till management. For the decade prior to seeding to continuous wheat, these plots were under either canola-wheat-flax-wheat or continuous canola. The W_WN plots were fertilized with $74.4 \mathrm{~kg} \mathrm{~N} \mathrm{ha}^{-1}$ (46-0-0); W-CNL plots were fertilized with $88 \mathrm{~kg} \mathrm{~N}^{-1}$ (46-0-0). The plots (plot dimensions: $6.4 \times 30.5 \mathrm{~m}$ ) were established as a randomized complete block design with four replications; all four plots (field replicates) were sampled for each crop rotation at Scott. The W-CNL and W-FP rotations were in their wheat phase for the 2009 sampling and their non-wheat phase for 2008 and 2010.

In 2009 and 2010, three rotations were sampled at Swift Current: wheat-lentil (Lens culinaris-Triticum aestivum cv. Lillian; W-L), continuous wheat without $\mathrm{N}$ fertilizer (W_0N), and continuous wheat with $\mathrm{N}$ fertilizer (W_WN; fertilization as for Scott W_WN). At Swift Current, the wheat-lentil rotations were established in 1979 and continuous wheat in 1967. Plots were managed with a stubble mulch tillage technique, designed to retain as much surface residues as possible. Three plots (field replicates) were sampled for each crop rotation at Swift Current. Each plot measured $10.5 \times 40 \mathrm{~m}$. Both phases of the W-L rotation were sampled each year.

Gross mineralization and nitrification: isotope dilution technique

For each rotation, gross mineralization and nitrification were measured up to three times during the growing season: pre-seeding (early May), anthesis (early- to mid-July) and post harvest (late August to September). All three growth stages/sampling dates were sampled at Scott in 2008, but the post-harvest sampling was extremely difficult due to very dry field conditions; hence, the post-harvest date was excluded at both sites in 2009 due to similarly dry conditions, but included again in the wetter 2010 season.

In each of the sampled plots, five intact soil cores $(15 \times 5 \mathrm{~cm}$ i.d.) were taken adjacent to one another between crop rows in order to minimize spatial variability. Crop residue was gently removed from the soil surface before core sampling. One of the five soil cores was used to determine gravimetric soil moisture content and bulk density. The remaining four cores were used to determine gross mineralization and nitrification with the $\mathrm{N}$ isotope dilution technique (Davidson et al. 1991). Briefly, immediately after collection, two cores were injected with $\left({ }^{15} \mathrm{NH}_{4}\right)_{2} \mathrm{SO}_{4}$ for gross mineralization measurements and two cores were injected with $\mathrm{K}^{15} \mathrm{NO}_{3}$ for gross nitrification measurements. An 18 gauge side-port spinal needle (Cadence Science, Lake Success, NY) was used to inject seven evenly spaced $2-\mathrm{mL}$ injections of ${ }^{15} \mathrm{~N}$ solution into each core $\left(30 \mu \mathrm{g} \mathrm{N} \mathrm{mL}^{-1}\right.$ at 99 at.\% ${ }^{15} \mathrm{~N}$ ); the concentrations were based on soil $\mathrm{N}$ levels and guidelines in the literature (Hart et al. 1994; Murphy et al. 2003). For each injection, the syringe was slowly compressed as the needle was withdrawn to evenly distribute the solution throughout the length of the core. Gravimetric moisture content increased on average $4.2 \%$ above the moisture content of the unlabeled cores. Within $30 \mathrm{~min}$ of injection, one core from the $\left({ }^{15} \mathrm{NH}_{4}\right)_{2} \mathrm{SO}_{4}$ labeled pair and one core from the $\mathrm{K}^{15} \mathrm{NO}_{3}$ labeled pair was extruded and homogenized. A $30 \mathrm{~g}$ soil subsample was taken and extracted with $100 \mathrm{~mL}$ of $2 \mathrm{M} \mathrm{KCl}$ (shaken on an oscillating shaker table at $150 \mathrm{rpm}$ for $45 \mathrm{~min}$ prior to extraction). The second core from each pair was buried to a depth of approximately $20 \mathrm{~cm}$ in the field for a 24-h incubation before being extracted. The exception to this incubation time was the nitrification assay in 2010, which was incubated for $18 \mathrm{~h}$, as outlined below. Extracts were analyzed for ${ }^{15} \mathrm{NH}_{4}{ }^{+}$and ${ }^{15} \mathrm{NO}_{3}{ }^{-}$using an acidified diffusion disk procedure as described by Hart et al. (1994) with the modification of using a polytetrafluoroethylene (PTFE) encased acid disk (Sørensen and Jensen 1991). Following diffusion, acid disks were removed and analyzed for $\mathrm{N}$ concentration and at. $\%{ }^{15} \mathrm{~N}$ using an ANCA-GSL elemental analyzer coupled to a continuous flow Tracer/20 mass spectrometer (Europa Scientific, SerCon Ltd., Cheshire, UK). Where $\mathrm{N}$ recovery on the acid disks was less than $100 \%$, concentrations were corrected following Stark and Hart (1996). 
Gross mineralization, nitrification, and consumption were calculated as described by Hart et al. (1994). There are a number of assumptions regarding the tracer kinetic equations proposed by Kirkham and Bartholomew (1954), which include: all rate processes can be described by zero-order kinetics over the incubation period; there is no isotopic discrimination of the mineral nutrient during transformation processes in the soil; labeled mineral $\mathrm{N}$ immobilized over the incubation period is not re-mineralized; the added label is homogeneously mixed with the soil inorganic pool (Hart et al. 1994). One possible consequence of violation of the re-mineralization assumption is negative gross production values. There were a substantial number of negative values in the 2008 study at Scott; based on this, the nitrification assay was not performed in 2009 at either site. A laboratory test conducted during 2009 indicated that there was indeed immobilization and re-mineralization of ${ }^{15} \mathrm{NO}_{3}{ }^{-}$during the 24-h incubation period, but that re-mineralization was not significant during an 18-h incubation. To this end, the nitrification assay was repeated in 2010, at both sites, using an 18-h incubation in lieu of a 24-h incubation as outlined above. There were still several negative values despite the shorter incubation period. All gross nitrification values for 2008 and 2010 are reported as calculated, including negative values where present, and will be discussed further below. Turnover rates (or mean residence times) on a given sampling date were calculated for the $\mathrm{NH}_{4}{ }^{+}$pool only as the $\mathrm{NH}_{4}{ }^{+}$pool size divided by the gross mineralization rate (Bedard-Haughn et al. 2006).

Source identification of $\mathrm{N}_{2} \mathrm{O}$ emissions: nitrification vs. denitrification

Source identification of $\mathrm{N}_{2} \mathrm{O}$ flux was determined at Scott in 2008 only. This was done in conjunction with the gross nitrification assay, using the injected ${ }^{15} \mathrm{NO}_{3}{ }^{-}$ as a tracer to identify the relative contributions of denitrification (from the labeled $\mathrm{NO}_{3}{ }^{-}$pool) versus nitrification-related processes (from the non-labeled organic $\mathrm{N}$ and $\mathrm{NH}_{4}{ }^{+}$pools); this was done according to the procedure described by Bedard-Haughn et al. (2006). The 24-h core of the $\mathrm{K}^{15} \mathrm{NO}_{3}$ labeled pair was placed into a $1.5 \mathrm{~L}$ Mason jar fitted with a septa in the lid. For $\mathrm{N}_{2} \mathrm{O}$ measurements, $\sim 15$ min after sealing the jar, initial $\left(\mathrm{T}_{0.25}\right)$ headspace samples were taken from each jar using a $20 \mathrm{~mL}$ syringe and injected into a
Labco Exetainer ${ }^{\circledR}$ vial (Labco, Limited, UK). The jars were then opened briefly for $\sim 5$ min to adjust the internal atmospheric pressure to ambient and to detect any $\mathrm{N}_{2} \mathrm{O}$ flux from core disturbance, then resealed and buried for a field incubation of $24 \mathrm{~h}$. After $24 \mathrm{~h}$, the jars were excavated and $\mathrm{T}_{24}$ headspace samples were taken. Samples were analyzed for total $\mathrm{N}_{2}$ and $\mathrm{N}_{2} \mathrm{O}$ as well as ${ }^{15} \mathrm{~N}_{2}$ and ${ }^{15} \mathrm{~N}_{2} \mathrm{O}$ at the University of California Davis Stable Isotope facility using a SerCon CryoPrep trace gas concentration system interfaced to a PDZ Europa 20-20 mass spectrometer (SerCon Ltd., Cheshire, UK). Ambient air samples were included as references in each analytical run to check for precision, detector drift and to calculate the minimum detectable concentration difference (MDCD). The MDCD was calculated according to Yates et al. (2006):

$\mathrm{MDCD}=\mu_{\text {pair diff }}+\left(2 \sigma_{\text {pair diff }}\right)$

where:

$\mu=$ average difference between sample pairs

$\sigma=$ standard deviation between sample pairs

If the $\mathrm{N}_{2} \mathrm{O}$ flux was less than the MDCD then the flux was considered to be not significantly different than 0 . The contribution of nitrification and denitrification to $\mathrm{N}_{2} \mathrm{O}$ flux was calculated according to Arah (1997) and Russow et al. (2008). An unlabeled set of soil cores (no added $\mathrm{NO}_{3}{ }^{-}$or water) was used to establish background levels of gas emissions during the incubation to determine whether there was an increase in emissions due to the method used.

\section{Statistical analyses}

Gross mineralization and nitrification results were analyzed by site with the linear mixed effects model in SPSS (IBM SPSS version 19.0 for Mac, 2010). The mixed approach was selected due to its suitability for correlated data (including repeated measures), unequal variances, and unbalanced designs. Year and sampling date variables were used to identify the repeated measures, with individual field plots as subjects. Crop rotation and sampling date were considered as factorial fixed effects and year was included as a random effect. Outliers $(n=7)$ were removed when they were greater than \pm 2.5 standard deviations. Normality was assessed using the ShapiroWilk test in SPSS (IBM SPSS version 19.0 for Mac, 
2010). There was no significant effect of year; these $P$ values are not reported. Mixed analyses were also performed with each of the following in place of rotation as one of the fixed factors: presence/absence of pulse in the rotation, phase, whether the current phase was a pulse crop, and whether the previous phase was a pulse crop; none of these improved the overall model over rotation, therefore results of these analyses are not shown. For comparison between the Scott and Swift Current sites, a similar mixed model was used, with the following changes: only the continuous wheat rotations (W_WN and W_ON) along with a pulse-wheat rotation (W-FP at Scott, W-L at Swift Current) were considered in the analysis, site was added as a fixed factor in the factorial effects, and presence/absence of pulses in the rotation was used in place of rotation as the fixed factor.

For the $\mathrm{N}_{2} \mathrm{O}$ source identification assay, flux was analyzed using the non-parametric Kruskal-Wallis Test; differences between individual rotations were tested for statistical significance using the MannWhitney-U procedure in SPSS (SPSS version 17.0 for Windows, 2007). Relationships between soil properties and $\mathrm{N}_{2} \mathrm{O}$-emitting processes were examined using Spearman's rank correlation (SPSS 2007).

For all tests, effects were declared significant at $P<0.10$ unless otherwise specified. Because of the inherent variability of field studies, a 0.10 level of significance was chosen to increase the likelihood that differences would be detected.

\section{Results}

Gross mineralization (ammonification)

Gross mineralization was highly variable at Scott, for all rotations and all years (Table 2). There were no significant effects of rotation $(P=0.3)$ or sampling date $(P=0.6)$. Ammonium consumption rates were slightly higher at anthesis than at pre-seeding or postharvest $(P=0.11)$ and significantly higher in the W-FP rotation (1.6 $\mathrm{mg} \mathrm{NH}_{4}{ }^{+}-\mathrm{N} \mathrm{kg}^{-1} \mathrm{~d}^{-1}$ ) than in the W-CNL rotation $\left(0.7 \mathrm{mg} \quad \mathrm{NH}_{4}^{+}-\mathrm{N} \mathrm{kg}^{-1} \mathrm{~d}^{-1}\right.$; $P=0.01$ ), but there were no other rotation effects on $\mathrm{NH}_{4}{ }^{+}$consumption. The $\mathrm{NH}_{4}{ }^{+}$pool sizes did not vary significantly by rotation, either (Table 6); overall values ranged from $1.7 \mathrm{mg} \mathrm{NH}_{4}{ }^{+}-\mathrm{N} \mathrm{kg}^{-1}$ soil in the W-FP rotation to $2.1 \mathrm{mg} \mathrm{NH}{ }^{+}-\mathrm{N} \mathrm{kg}^{-1}$ soil in the
W_WN rotation with an overall average of $2.0 \pm 1.3 \mathrm{mg} \mathrm{NN_{4 }}{ }^{+}-\mathrm{N} \mathrm{kg}^{-1}$ soil. Although W-FP had a slightly longer mean $\mathrm{NH}_{4}{ }^{+}$turnover time $(2.2 \pm 0.4 \mathrm{~d})$, it did not differ significantly from the other rotations $(1.8 \pm 0.4 \mathrm{~d}$ for $\mathrm{C}-\mathrm{W} ; 1.5 \pm 0.5$ for W_0N; $1.4 \pm 0.5$ for W_WN).

At Swift Current (Table 3), there was a significant effect of both rotation $(P=0.1)$ and sampling date $(P=0.02)$ on gross mineralization, but no interaction effect, with the highest rates associated with the W_WN rotation $\left(2.27 \mathrm{mg} \mathrm{NH}_{4}{ }^{+}-\mathrm{N} \mathrm{kg}^{-1} \mathrm{~d}^{-1}\right)$. It was significantly higher than both the W_0N $(1.21 \mathrm{mg}$ $\left.\mathrm{NH}_{4}{ }^{+}-\mathrm{N} \mathrm{kg}^{-1} \mathrm{~d}^{-1}, P=0.08\right)$ and $\mathrm{W}-\mathrm{L}(0.98 \mathrm{mg}$ $\left.\mathrm{NH}_{4}{ }^{+}-\mathrm{N} \mathrm{kg}^{-1} \mathrm{~d}^{-1}, P=0.05\right)$ rotations. Anthesis had significantly higher rates than pre-seeding $(P=0.01)$. The W_WN rotation also had significantly higher rates of $\mathrm{NH}_{4}{ }^{+}$consumption than $\mathrm{W} \_0 \mathrm{~N}$ or W-L $(P=0.01$ and 0.04 , respectively). There was no effect of sampling date or rotation on $\mathrm{NH}_{4}^{+}$consumption $(P=0.2$ and 0.7 , respectively). Ammonium concentrations (Table 6) ranged from $1.5 \pm 0.5 \mathrm{mg} \mathrm{NH}_{4}{ }^{+}$$\mathrm{N} \mathrm{kg}^{-1}$ soil in the $\mathrm{W} \_0 \mathrm{~N}$ rotation to $1.8 \pm 0.8 \mathrm{mg}$ $\mathrm{NH}_{4}{ }^{+}-\mathrm{N} \mathrm{kg}^{-1}$ soil in the W-L rotation and $2.0 \pm 2.0 \mathrm{mg} \mathrm{NH}_{4}{ }^{+}-\mathrm{N} \mathrm{kg}^{-1}$ soil in the $\mathrm{W} \_\mathrm{WN}$ rotation; there were no significant differences among rotations. Mean $\mathrm{NH}_{4}{ }^{+}$turnover rates did not differ significantly among rotations $\left(1.5 \pm 2.3 \mathrm{~d}\right.$ for $\mathrm{W} \_0 \mathrm{~N}$; $5.2 \pm 2.3 \mathrm{~d}$ for W_WN; $2.0 \pm 2.3$ for W-L).

The comparison between the Scott and Swift Current sites examined the effect of pulses in the rotation, not the specific crop; the mixed model took into consideration only the continuous wheat rotations versus the wheat-pulse rotations (W-FP and W-L at Scott and Swift Current, respectively). There was a significant effect of presence of pulses in the rotation, with higher mineralization rates under the continuous wheat rotations (1.40 vs. $0.97 \mathrm{mg} \mathrm{NH}_{4}{ }^{+}-\mathrm{N} \mathrm{kg}^{-1} \mathrm{~d}^{-1}$; $P=0.06$ ), although this difference would be driven primarily by the significantly higher $\mathrm{W}_{\text {_WN }}$ rates at Swift Current. Due to the higher rates at anthesis, there was a significant effect of sampling date $(P=0.01)$, but there was no effect of site $(P=0.9)$.

Gross nitrification

There was no significant effect of rotation $(P=0.2)$ or sampling date $(P=0.4)$ on gross nitrification rates at Scott (Table 4). Rates were highly variable, ranging from theoretically impossible negative values up to 


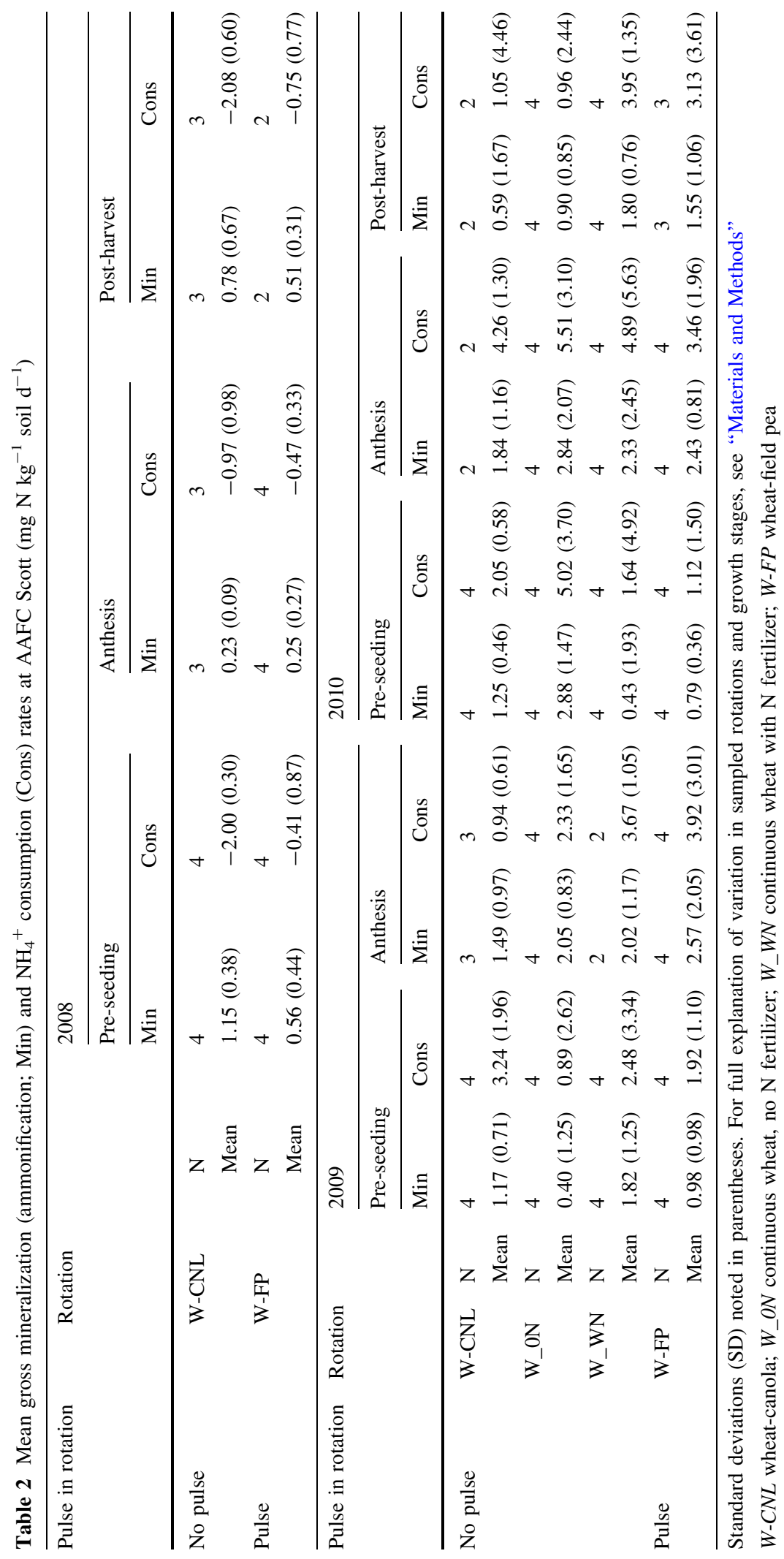




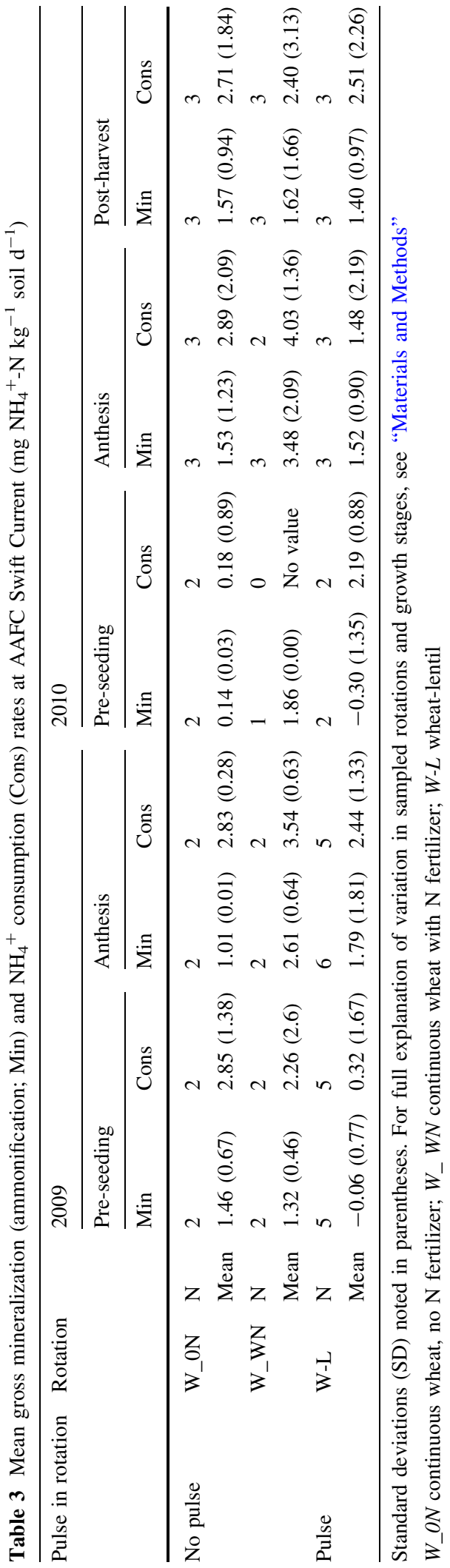

$6.5 \mathrm{mg} \mathrm{NO}_{3}{ }^{-}-\mathrm{N} \mathrm{kg}^{-1} \mathrm{~d}^{-1}$ in the $\mathrm{W} \_0 \mathrm{~N}$ rotation. The negative nitrification values most likely represent a violation of one or more assumptions of the isotope dilution method; the implications will be discussed further below. Soil $\mathrm{NO}_{3}{ }^{-}$concentrations were higher than $\mathrm{NH}_{4}{ }^{+}$, but did not vary significantly by rotation ranging from $4.3 \pm 2.0 \mathrm{mg} \mathrm{NO}_{3}{ }^{-}-\mathrm{N} \mathrm{kg}^{-1}$ soil in W_WN to $5.1 \pm 2.1 \mathrm{mg} \mathrm{NO}_{3}{ }^{-}-\mathrm{N} \mathrm{kg}^{-1}$ soil in W-FP (overall mean $=4.7 \pm 1.9 \mathrm{mg} \mathrm{NO}_{3}{ }^{-} \mathrm{N} \mathrm{kg}^{-1}$ soil). At Swift Current, there was a significant effect of rotation $(P=0.1)$ and sampling date $(P=0.1)$, reflecting much lower measured nitrification rates for the W_WN rotation $\left(-0.02 \mathrm{mg} \mathrm{NO}_{3}{ }^{-}-\mathrm{N} \mathrm{kg}^{-1} \mathrm{~d}^{-1}\right)$ compared to the W_0N (1.60 $\left.\mathrm{mg} \mathrm{NO}_{3}{ }^{-}-\mathrm{N} \mathrm{kg}^{-1} \mathrm{~d}^{-1}\right)$ or W-L $\left(2.10 \mathrm{mg} \quad \mathrm{NO}_{3}{ }^{-}-\mathrm{N} \mathrm{kg}^{-1} \mathrm{~d}^{-1}\right)$ rotations (Table 5). Once again, the mean negative value for W_WN is theoretically impossible and likely reflects methodological constraints. There was no significant effect of rotation or sampling date on $\mathrm{NO}_{3}{ }^{-}$-consumption rates at either site. Soil $\mathrm{NO}_{3}{ }^{-}$concentrations

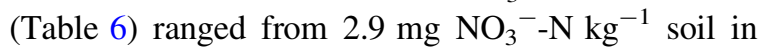
$\mathrm{W} \_\mathrm{N}$ to $3.1 \mathrm{mg} \mathrm{NO}_{3}{ }^{-}-\mathrm{N} \mathrm{kg}^{-1}$ soil in W-L and $3.7 \mathrm{mg}$ $\mathrm{NO}_{3}{ }^{-}-\mathrm{N} \mathrm{kg}^{-1}$ soil in $\mathrm{W}_{-} \mathrm{WN}$ (mean $=3.2 \pm 1.8 \mathrm{mg}$ $\mathrm{NO}_{3}{ }^{-}-\mathrm{N} \mathrm{kg}^{-1}$ soil).

Comparison of the Scott and Swift Current sites with respect to gross nitrification found no significant effect of site $(P=0.4)$, but there was again a significant effect of presence/absence of pulses in rotation $(P=0.03)$ and interactions between both sampling*site $(P=0.07)$ and sampling*pulse $(P=0.04)$. Measured gross nitrification rates were higher when pulses were in the rotation $(1.85 \mathrm{mg}$ $\mathrm{NO}_{3}{ }^{-}-\mathrm{N} \mathrm{kg}^{-1} \mathrm{~d}^{-1}$ ), compared to the continuous wheat rotations $\left(0.59 \mathrm{mg} \mathrm{NO}{ }^{-}-\mathrm{N} \mathrm{kg}^{-1} \mathrm{~d}^{-1}\right)$, but this will also reflect the negative values associated with continuous wheat rotations at both sites (Tables 4, 5).

Source of $\mathrm{N}_{2} \mathrm{O}$ emissions: nitrification vs. denitrification

In the 2008 incubation study to examine the source of $\mathrm{N}_{2} \mathrm{O}$ from the Scott rotations, mean $\mathrm{N}_{2} \mathrm{O}$ emissions after $24 \mathrm{~h}$ incubation were low for all sampling dates and ranged from 0 to $5.7 \mathrm{ng} \mathrm{N} \mathrm{N}_{2} \mathrm{O}-\mathrm{N} \mathrm{m}^{2} \mathrm{~s}^{-1}$ (Table 7). There was no significant difference in $\mathrm{N}_{2} \mathrm{O}$ emissions among the rotations for any of the sampling dates. There was, however, a significant effect of the added label, which caused a flush of $\mathrm{N}_{2} \mathrm{O}$ emissions above 


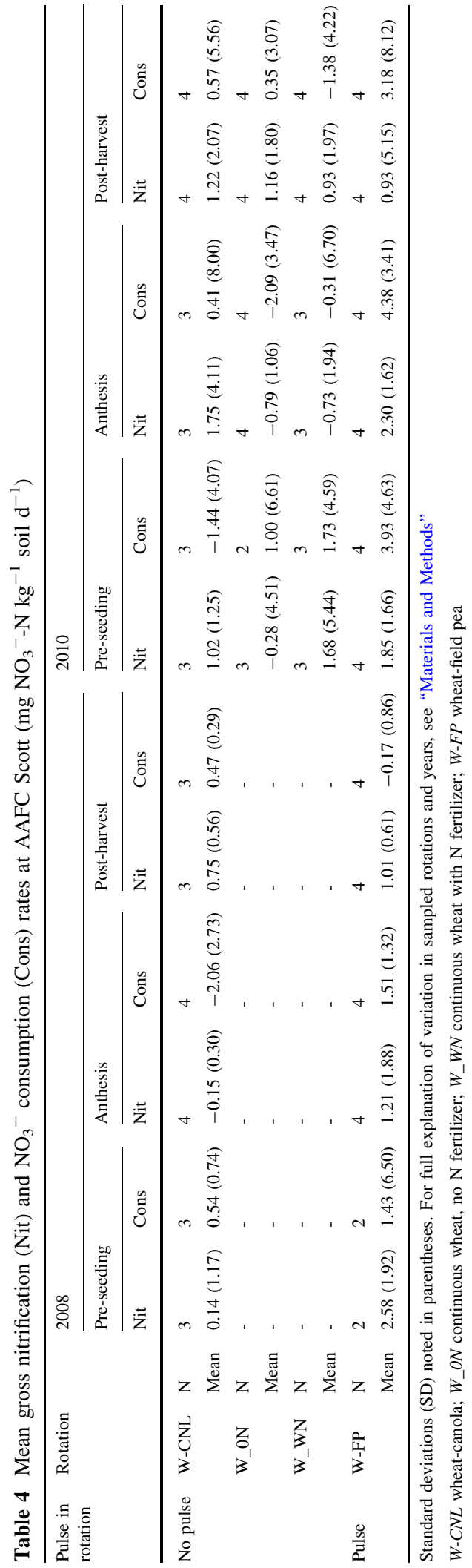

and beyond the background levels for all dates and sampling times $\left(\mathrm{T}_{24}\right.$ and $\left.\mathrm{T}_{0.25}\right)$ except for $\mathrm{T}_{0.25}$ at preseeding. Soil moisture content at pre-seeding was 10.7 and $12.1 \%$ higher than at anthesis and post-harvest, respectively, which is why there may not have been an immediate effect of the added enriched solution at preseeding for the $T_{0.25}$ samples. Mean WFPS of the $T_{24}$ $\mathrm{K}^{15} \mathrm{NO}_{3}$ labeled cores at pre-seeding, anthesis and post-harvest was 39.9, 24.6 and $23.1 \%$, respectively. There were significant correlations between soil $\mathrm{NH}_{4}{ }^{+}$ concentrations and the $\mathrm{N}_{2} \mathrm{O}$ flux from the labeled cores at $\mathrm{T}_{0.25}\left(\mathrm{r}_{\mathrm{s}}=0.455, P=0.001\right)$, the non-labeled cores at $\mathrm{T}_{0.25} \quad\left(\mathrm{r}_{\mathrm{s}}=0.546, P=0.0001\right)$, and the non-labeled cores at $\mathrm{T}_{24}\left(\mathrm{r}_{\mathrm{s}}=0.372, P=0.005\right)$. Overall, nitrification-related processes contributed $96.9-99.4 \%$ of the $\mathrm{N}_{2} \mathrm{O}$ flux.

\section{Discussion}

Effect of pulse crops in the rotation

There is a general acceptance that including pulse crops in rotation will result in $\mathrm{N}$ benefits that extend beyond $\mathrm{N}$ fixation including reduced inorganic $\mathrm{N}$-uptake by pulses in comparison with non-pulses, better plant residue quality, higher SOM turnover, and a greater amount and quality of rhizodeposits (Chalk 1998; Mayer et al. 2003; Lemke et al. 2007), all of which should be reflected in rates of $\mathrm{N}$ cycling. The overall gross mineralization and nitrification rates in this study were within the range of previously reported values for agricultural land (Booth et al. 2005). However, we found no difference among rotations with versus without pulses, with the exception of the higher mineralization rates in continuous wheat rotations than pulse-wheat rotations when considered across both sites. Much of this difference would have been driven by higher rates in the $\mathrm{W}_{-} \mathrm{WN}$ rotation (Tables 2, 3); $\mathrm{N}$ fertilization is known to increase soil microbial activity and accelerate SON cycling (Shah et al. 2010; Zhang et al. 2012).

Net $\mathrm{N}$ benefits-of any crop-will reflect the interacting factors of residue quantity (above- and below-ground) and quality (biochemical composition, $\mathrm{C}: \mathrm{N}$ ratio, etc.). Most studies of $\mathrm{N}$ benefits from legumes have been conducted based on a comparison of cereal versus pulse crops (Lemke et al. 2007; Lupwayi and Soon 2009); however, accumulation of 
Table 5 Mean gross nitrification (Nit) and $\mathrm{NO}_{3}{ }^{-}$consumption (Cons) rates at AAFC Swift Current $\left(\mathrm{mg} \mathrm{NO}_{3}^{-}-\mathrm{N} \mathrm{kg}^{-1}\right.$ soil d $\left.{ }^{-1}\right)$, which was only quantified in 2010

\begin{tabular}{|c|c|c|c|c|c|c|c|c|}
\hline \multirow[t]{3}{*}{ Pulse in rotation } & \multirow[t]{3}{*}{ Rotation } & & \multicolumn{6}{|l|}{2010} \\
\hline & & & \multicolumn{2}{|l|}{ Pre-seeding } & \multicolumn{2}{|l|}{ Anthesis } & \multicolumn{2}{|l|}{ Post-harvest } \\
\hline & & & Nit & Cons & Nit & Cons & Nit & Cons \\
\hline \multirow[t]{4}{*}{ No pulse } & W_0N & $\mathrm{N}$ & 3 & 3 & 3 & 3 & 3 & 3 \\
\hline & & Mean & $0.84(0.72)$ & $0.20(1.82)$ & $3.28(3.55)$ & $4.91(6.17)$ & $0.68(1.24)$ & $0.90(2.75)$ \\
\hline & W_WN & $\mathrm{N}$ & 3 & 3 & 3 & 2 & 3 & 3 \\
\hline & & Mean & $0.93(1.83)$ & $0.32(3.44)$ & $-1.65(1.01)$ & $-2.84(3.19)$ & $0.65(1.41)$ & $3.12(3.12)$ \\
\hline \multirow[t]{2}{*}{ Pulse } & W-L & $\mathrm{N}$ & 3 & 3 & 3 & 3 & 3 & 3 \\
\hline & & Mean & $2.41(2.96)$ & $1.92(3.93)$ & $4.77(1.42)$ & $7.06(3.62)$ & $-0.90(2.38)$ & $0.14(2.45)$ \\
\hline
\end{tabular}

Standard deviations (SD) noted in parentheses. For full explanation of variation in sampled rotations and years, see "Materials and Methods"

$W \_O N$ continuous wheat, no $\mathrm{N}$ fertilizer; $W_{-} W N$ continuous wheat with $\mathrm{N}$ fertilizer; $W-L$ wheat-lentil

Table 6 Mean $\mathrm{NH}_{4}{ }^{+}$and $\mathrm{NO}_{3}{ }^{-}$concentrations at AAFC Scott and AAFC Swift Current (mg N kg${ }^{-1}$ soil), averaged across all years

\begin{tabular}{|c|c|c|c|c|c|c|c|c|}
\hline Pulse in rotation & Rotation & & $\begin{array}{l}\text { Pre-seeding } \\
\mathrm{NH}_{4}{ }^{+}\end{array}$ & $\mathrm{NO}_{3}{ }^{-}$ & $\begin{array}{l}\text { Anthesis } \\
\mathrm{NH}_{4}^{+}\end{array}$ & $\mathrm{NO}_{3}{ }^{-}$ & $\begin{array}{l}\text { Post-harvest } \\
\mathrm{NH}_{4}{ }^{+}\end{array}$ & $\mathrm{NO}_{3}^{-}$ \\
\hline \multicolumn{9}{|l|}{ AAFC Scott } \\
\hline \multirow[t]{6}{*}{ No pulse } & W-CNL & $\mathrm{N}$ & 12 & 6 & 11 & 7 & 5 & 7 \\
\hline & & Mean & $1.35(1.02)$ & $4.78(2.33)$ & $2.65(2.02)$ & $4.22(1.81)$ & $2.32(1.43)$ & $4.86(1.09)$ \\
\hline & W_ON & $\mathrm{N}$ & 8 & 3 & 8 & 4 & 4 & 4 \\
\hline & & Mean & $2.63(1.23)$ & $6.42(1.27)$ & $1.93(1.06)$ & $3.28(1.87)$ & $1.9(1.18)$ & $4.08(1.07)$ \\
\hline & W_WN & $\mathrm{N}$ & 8 & 3 & 7 & 3 & 4 & 4 \\
\hline & & Mean & $2.69(1.67)$ & $6.17(1.55)$ & $1.9(1.23)$ & $2.92(2.5)$ & $1.26(0.8)$ & $3.92(0.98)$ \\
\hline \multirow[t]{2}{*}{ Pulse } & W-FP & $\mathrm{N}$ & 12 & 7 & 12 & 8 & 6 & 8 \\
\hline & & Mean & $1.54(0.95)$ & $6.06(3.25)$ & $2.03(0.99)$ & $4.06(1.3)$ & $1.29(1.1)$ & $5.42(0.88)$ \\
\hline \multicolumn{9}{|c|}{ AAFC Swift Current } \\
\hline \multirow[t]{4}{*}{ No pulse } & W_0N & $\mathrm{N}$ & 5 & 3 & 5 & 3 & 3 & 3 \\
\hline & & Mean & $1.72(0.37)$ & $3.95(0.44)$ & $1.44(0.62)$ & $1.52(0.61)$ & $1.37(0.29)$ & $3.12(0.78)$ \\
\hline & W_WN & $\mathrm{N}$ & 4 & 3 & 5 & 3 & 3 & 3 \\
\hline & & Mean & $2.22(1.15)$ & $4.13(0.6)$ & $2.44(3.03)$ & $4.42(3.68)$ & $1.11(0.41)$ & 2.45 (1.72) \\
\hline \multirow[t]{2}{*}{ Pulse } & W-L & $\mathrm{N}$ & 7 & 3 & 8 & 3 & 3 & 3 \\
\hline & & Mean & $1.75(0.92)$ & $4.37(0.27)$ & $2.05(0.65)$ & $1.02(0.44)$ & $1.47(0.87)$ & $4.01(1.44)$ \\
\hline
\end{tabular}

Standard deviations (SD) noted in parentheses. For full explanation of variation in sampled rotations and years, see "Materials and Methods"

$W$-CNL wheat-canola; $W \_O N$ continuous wheat, no $\mathrm{N}$ fertilizer; $W \_W N$ continuous wheat with $\mathrm{N}$ fertilizer; $W$ - $F P$ wheat-field pea; $W$ $L$ wheat-lentil

mineral $\mathrm{N}$ has been associated with both pulse and canola (oilseed) crops (Kirkegaard et al. 1999; Ryan et al. 2006). In a comparison of wheat, oilseeds and pulses at the Swift Current site, Gan et al. (2010) observed maximum accumulation of $\mathrm{NO}_{3}{ }^{-}-\mathrm{N}$ under wheat, but similar accumulations between oilseeds and pulses (including field pea and lentil). Canola and wheat were also found to have comparable root $\mathrm{N}$ ( $\mathrm{kg} \mathrm{N} \mathrm{ha}^{-1}$ ) compared to pulse crops (Gan et al. 2010) indicating that despite the ability of pulse crops to fix their own $\mathrm{N}$, the below-ground residues may not have a greater contribution to the net $\mathrm{N}$ benefit compared to fertilized wheat or oilseeds. Interestingly, they also observed similar apparent net $\mathrm{N}$ mineralization under 


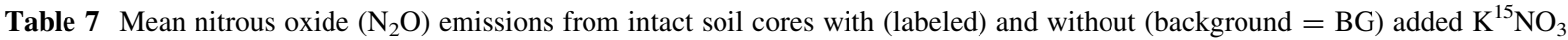
$(\mathrm{n}=4)$

\begin{tabular}{|c|c|c|c|c|c|c|c|}
\hline \multirow[t]{2}{*}{ Date $^{\mathrm{a}}$} & \multirow[t]{2}{*}{ Rotation $^{\mathrm{b}}$} & \multicolumn{3}{|c|}{$\mathrm{T}_{0.25} \mathrm{~N}_{2} \mathrm{O}$ Flux (ng $\mathrm{N}_{2} \mathrm{O}-\mathrm{N} \mathrm{m}^{2} \mathrm{~s}^{-1}$ ) } & \multicolumn{3}{|c|}{$\mathrm{T}_{24} \mathrm{~N}_{2} \mathrm{O}$ Flux (ng $\left.\mathrm{N}_{2} \mathrm{O}-\mathrm{N} \mathrm{m}^{2} \mathrm{~s}^{-1}\right)$} \\
\hline & & BG & Labeled & $\% \mathrm{Nit}$ & BG & Labeled & $\% \mathrm{Nit}$ \\
\hline \multirow[t]{2}{*}{ Pre-seeding } & W-FP & $0^{\mathrm{c}}$ & 0 & $\mathrm{n} / \mathrm{a}$ & $0.4(0.4)$ & $1.6(0.6)$ & 97.7 (1.1) \\
\hline & W-CNL & 0 & 0 & $\mathrm{n} / \mathrm{a}$ & $0.4(0.3)$ & $2.0(0.7)$ & $98.0(0.8)$ \\
\hline \multirow[t]{2}{*}{ Anthesis } & W-FP & 10.7 (3.6) & 79.6 (31.9) & $99.5(0.0)$ & $0.3(0.1)$ & $1.8(0.4)$ & $99.4(0.0)$ \\
\hline & W-CNL & $3.6(3.6)$ & $80.0(29.3)$ & $99.5(0.1)$ & $0.8(0.5)$ & $2.1(0.5)$ & $99.0(0.4)$ \\
\hline \multirow[t]{2}{*}{ Post-harvest } & W-FP & 0 & $28.0(11.3)$ & $99.5(0.0)$ & $0.3(0.3)$ & $0.5(0.3)$ & $98.8(0.3)$ \\
\hline & W-CNL & 0 & $23.2(13.4)$ & $99.5(0.0)$ & 0 & $0.4(0.2)$ & $98.9(0.2)$ \\
\hline
\end{tabular}

Standard error values given in parentheses. Gas samples were taken after $15 \mathrm{~min}\left(\mathrm{~T}_{0.25}\right)$ and again after a 24-h in situ incubation $\left(\mathrm{T}_{24}\right)$. The proportion of the $\mathrm{N}_{2} \mathrm{O}$ flux attributed to nitrification-related processes is shown (\% Nit). This experiment was carried out at AAFC Scott in 2008

${ }^{\text {a }}$ In 2008, Pre-seeding = May 13, Anthesis = July 8, Post-harvest $=$ October 8

b Underlining indicates the crop phase sampled; $W$-FP wheat-field pea, $W$ - $C N L$ wheat-canola

c The 0 values for $\mathrm{N}_{2} \mathrm{O}$ flux represent the values where emissions were $<\mathrm{MDCD}$

wheat and pulses, but rates under oilseeds were about $50 \%$ lower (Gan et al. 2010). This last finding may be supported by Sangster et al. (2010), who found significantly higher total root biomass in canola compared to field pea (including both living biomass and root exudates, quantified using ${ }^{13} \mathrm{C}$ labeling), but also noted that based on its biochemical composition, canola root biomass was likely more recalcitrant than field pea root biomass. There have also been reports of narrower $\mathrm{C}: \mathrm{N}$ ratios in pulse crop root and shoot biomass, which enhances $\mathrm{N}$ availability in the soil (Miller et al. 2006). For example, under non-irrigated conditions at Swift Current, Gan et al. (2011) found straw C:N ratios of 14.8 for field pea and 19.3 for lentil, versus 33.0 for canola and 40.9 for wheat; root C:N ratios were 20.0 for field pea and 30.0 for lentil, versus 54.6 for canola and 43.4 for wheat. The results of these studies suggest that over the longer term represented in our rotational comparison, the higher quantity of relatively recalcitrant non-pulse roots may be balanced by the lower inputs of more labile pulse residues. This balance of quality and quantity, coupled with the aforementioned fertilizer effect, may have resulted in the comparable gross mineralization rates observed among rotations.

Mineralization rates for all rotations tended to increase over the growing season. The significantly higher mineralization rates at anthesis could be due to warmer soil temperatures, which would lead to greater microbial activity (Madigan et al. 2010), particularly when coupled with normal to above-normal soil moisture. The findings of a study in Australia found seasonal variation in moisture (i.e., wet-dry cycles) had a greater impact on the timing of soil $\mathrm{N}$ supply than the crop type (Hoyle and Murphy 2011). However, substrate availability is a major factor regulating inorganic $\mathrm{N}$ production. During pod filling in pulse crops, large quantities of readily mineralizable $\mathrm{N}$-compounds are lost from roots (Ofosu-Budu et al. 1990). Wichern et al. (2008) found that the inorganic $\mathrm{N}$ content at crop maturity-and the proportion derived from rhizodeposition-was much higher under pea than oat, and that during the reproductive growth phase, existing roots die and therefore contribute to rhizodeposition, which could further drive mineralization. The increasing mineralization rates over the growing season may therefore reflect the cumulative rhizodeposition that occurs during the vegetative phase resulting in higher gross mineralization rates at anthesis.

\section{Methodological and biological considerations}

Although the isotope dilution technique used here to quantify gross mineralization and nitrification has many advantages over more static measures of pool size or potential net measurements of $\mathrm{N}$ dynamics, it does have some limitations. The results presented here provide a good estimate of nitrogen dynamics in pulse 
versus non-pulse rotations, but the presence of several negative production rates suggests the violation of one or more methodological assumptions.

The first, and most plausible, explanation for negative gross values is violation of the immobilization and re-mineralization assumption, where the added ${ }^{15} \mathrm{~N}$ is re-mineralized within the 24 -h incubation period. Although it has been proposed that this is more likely to occur in mineralization assays (Murphy et al. 2003), the 2008 gross nitrification results (Table 4) and results of the controlled laboratory experiment designed to determine an optimum incubation time (results not shown) indicated that substantial $\mathrm{NO}_{3}{ }^{-}$ immobilization and re-nitrification was occurring. In the controlled laboratory experiment, ${ }^{15} \mathrm{~N}$ enrichment of the $\mathrm{NO}_{3}{ }^{-}$pool decreased over the first $18 \mathrm{~h}$ of the incubation, but by $24 \mathrm{~h}$, began to increase again, indicating recycling of the added ${ }^{15} \mathrm{~N}$. This may be attributed to rapid microbial immobilization and renitrification, or alternatively, to dissimilatory nitrate reduction to ammonium (DNRA). This process is not well studied in the Northern Great Plains, or in arable soils in general. Maximum DNRA rates have been reported in humid soils with high soil carbon, such as temperate and tropical rainforests, but its relative importance to total $\mathrm{NO}_{3}{ }^{-}$consumption may actually be greater in less humid soils (Rutting et al. 2011). Preliminary assessments of conditions conducive to DNRA in temperate agricultural soils indicate that there is indeed potential for this process to be of significance, but that detecting it in situ may be difficult unless there is a low molecular weight $\mathrm{C}$ source already present in the system (Schmidt et al. 2011).

A second important consideration is the effect of injecting the label in solution in intact, semi-arid soils. Although both soils were medium-textured (Table 1), there were stones present at both sites, which made it very difficult to insert the injection needle straight into the cores, and particularly difficult to ensure that all injections were evenly distributed throughout the core. This issue of non-uniformity was further exacerbated under dry conditions as experienced in the fall of 2008 and 2009. By post-harvest 2008, the soils had dried in the field to the point where it was almost impossible to insert the needles into the cores at all, and the extreme dryness further limited the potential for the injected solution to diffuse evenly throughout the core. Under these very dry conditions, it is also unclear what effect the sudden introduction of N-rich solution might have on the microbial community. Saetre and Stark (2005) found that the wetting up of a previously dry soil in Wyoming triggered a rapid increase in $\mathrm{C}$ cycling rates, which in turn released an $\mathrm{N}$-rich substrate pool that resulted in a pulse of gross and net mineralization. This same phenomenon could have occurred on a micro-site scale within the dry cores, contributing to highly variable results and potentially to the negative results as well.

A third consideration, which has not been specifically addressed in agricultural assessments of gross mineralization/nitrification, is the potential impact of conservation tillage practices on meso-scale heterogeneity, and the consequences of that variability in application of the isotope dilution technique. Conservation tillage has replaced conventional tillage-intensive systems through much of the semi-arid Northern Great Plains. With this, there has been an accumulation of partially decomposed residues on the soil surface and slower decomposition of both above- and below-ground residues due to lack of incorporation via tillage (Curtin et al. 2000). As a result, root biomass from the previous seasons is not redistributed throughout the tillage layer but rather decomposes in a clump, creating hot spots within the soil that may not be evident at the soil surface. Hence, even when efforts are made to ensure that all cores are taken between rows and as close together as possible (as was the case here), these hot spots may mean that each core in the pair differs substantially in initial substrate level, contributing to highly variable and/or negative results. In hindsight, it may have been preferable to use disturbed soil samples to ensure that the paired samples are reasonably homogeneous. However, using disturbed samples would undoubtedly increase the gross cycling rates (Kaur et al. 2010), providing a measure more representative of potential production than actual production.

Regardless of the source of the error, it is evident that negative gross values are ecologically impossible. Although many studies either omit negative values or truncate them to zero, they have been included here to promote discussion and encourage further research in this area. These negative values can be interpreted as an indicator of difference (i.e., where gross nitrification rates differed between W_L and W_ON versus W_WN rotations at Swift Current); but the exact nature of the difference should not be interpreted as causal without further experimentation. 
Nitrous oxide source identification

Denitrification is associated with anaerobic soils with greater than $60 \%$ water-filled pore space, low N, and high C (Wrage et al. 2001), whereas autotrophic nitrification is associated with well-aerated soils with high $\mathrm{N}$ contents (Wrage et al. 2001; Booth et al. 2005). Conditions of water saturation are generally rare at this particular site so it was not surprising that the major contribution of $\mathrm{N}_{2} \mathrm{O}$ flux would be from the nitrification pathway. The positive correlation of $\mathrm{NH}_{4}{ }^{+}$to $\mathrm{T}_{24}$ $\mathrm{N}_{2} \mathrm{O}$ flux of the labeled field-incubated cores supports the conclusion that 96-99\% of emissions were from nitrification related processes (including nitrification, coupled nitrification-denitrification, or nitrifier denitrification), further highlighting the importance of this pathway for $\mathrm{N}_{2} \mathrm{O}$ flux in semi-arid agricultural ecosystems (Bedard-Haughn et al. 2006; Ma et al. 2008; Wan et al. 2009).

The $\mathrm{N}_{2} \mathrm{O}$ emissions in this in-field incubation study were in the lower range of emissions according to measurements for semi-arid agricultural systems within the Northern Great Plains, ranging from mean fluxes of 97.2 to $-0.2 \mathrm{ng} \mathrm{N} \mathrm{N}_{2} \mathrm{O}-\mathrm{N} \mathrm{m}^{-2} \mathrm{~s}^{-1}$ (Corre et al. 1996; Lemke et al. 1998; Yates et al. 2006). There have been many reports of soil amended with different crop residues and the corresponding differences in $\mathrm{N}_{2} \mathrm{O}$ emissions (Aulakh et al. 1991; McKenney et al. 1993; Shelp et al. 2000), so it was unexpected that we found no significant effect of crop rotation. Lemke et al. (2002) reported that during the growing season, $\mathrm{N}_{2} \mathrm{O}$ emissions from field pea and lentil crops were significantly lower than from fertilized cereal crops and found that emissions generally reflected $\mathrm{N}$ fertilizer inputs. Nitrogen fertilizer applications to agricultural soils normally increase $\mathrm{N}$ oxide emission (Mosier et al. 2006). In our study, fertilization of crop rotations occurred just after the initial $\mathrm{N}_{2} \mathrm{O}$ measurement at pre-seeding so any flux attributed to applied $\mathrm{N}$ most likely was missed.

Negative correlations have been reported between $\mathrm{C}: \mathrm{N}$ ratios of crop residues and $\mathrm{N}_{2} \mathrm{O}$ emissions (Baggs et al. 2000; Huang et al. 2004). Pulse residues are reported to have lower $\mathrm{C}: \mathrm{N}$ ratios relative to wheat and oilseed crops (Janzen and Kucey 1988; Gan et al. 2011) and therefore could result in higher $\mathrm{N}_{2} \mathrm{O}$ emissions. Ellert and Janzen (2008) suggest $\mathrm{N}_{2} \mathrm{O}$ increases under low $\mathrm{C}: \mathrm{N}$ crop residues is likely due to an increase in $\mathrm{N}$ available for nitrification and possibly denitrification. Hadas et al. (2004) reported that lower
$\mathrm{C}: \mathrm{N}$ residues have higher water-soluble organic $\mathrm{C}$. Therefore, the soluble $\mathrm{C}$ could serve as a substrate for denitrifiers and the increase in heterotrophic activity would result in a consumption of oxygen creating temporary anaerobic microsites (Ellert and Janzen 2008).

There appeared to be an effect of core disturbance on $\mathrm{N}_{2} \mathrm{O}$ flux. The increase in $\mathrm{T}_{0.25}$ fluxes from labeled soil cores is likely due to a stimulatory effect on microbes of adding the $\mathrm{K}^{15} \mathrm{NO}_{3}$ solution or simply a displacement affect where the $\mathrm{K}^{15} \mathrm{NO}_{3}$ solution displaced a volume of soil gas. This stimulation and displacement effect across the treatments might have masked rotational differences. However, the $T_{0.25}$ background cores at anthesis also showed fluxes greater than the $\mathrm{T}_{24}$ measurements.

\section{Conclusion}

The similarities in $\mathrm{N}$ dynamics across the rotations included in this study reflect the interacting effects of residue quantity and quality. At both of these Northern Great Plains sites, the higher quantity of residue inputs associated with the non-pulse rotations did not translate into higher gross mineralization rates than the lower-biomass pulse crops; nor did the continuous wheat rotations differ significantly unless fertilizer was added. The lower C:N ratio and greater biochemical lability associated with pulse crops appears to offset the difference in quantity, such that all rotations have similar production rates. Therefore the overall benefit to pulse crops in the rotation, from an $\mathrm{N}$ dynamics perspective, is that their smaller quantity of $\mathrm{N}$-rich residues can contribute equal amounts of $\mathrm{N}$ to succeeding crops compared to more input-intensive cereals and oilseeds.

Although $\mathrm{N}$ contributions from pulse residues may also contribute to slightly higher $\mathrm{N}_{2} \mathrm{O}$ emissions from nitrification under some conditions, the overall emission rates in these semi-arid soils are generally quite low. Where high emissions are a concern, nitrification inhibitors may be worth exploring. Further assessments of the potential contribution of DNRA to $\mathrm{NO}_{3}{ }^{-}$ dynamics are also required for the Northern Great Plains. Better understanding of this process may contribute to improved $\mathrm{N}$ management plans as well as improved methodologies for assessing $\mathrm{N}$ dynamics in semi-arid systems. In a similar vein, future work on 
gross $\mathrm{N}$-cycling in agro-ecosystems should consider (a) the optimum incubation time based on local preliminary analyses, (b) the effects of wetting up on gross $\mathrm{N}$ rates, and (c) the risks and benefits of using intact cores under conservation tillage. Where intact cores are deemed necessary, much greater spatial and temporal replication is recommended, although this will significantly increase the cost of an already expensive procedure.

Acknowledgments This project received financial support from the Pulse Research Network (PURENet) - part of the Agricultural Bioproducts Innovation Program (ABIP) of Agriculture and Agri-Food Canada (AAFC) - and the Saskatchewan Pulse Growers. Thanks to the scientists and staff at the AAFC Scott and Swift Current Research Farms, the Stable Isotope Laboratory, and the many students and staff who assisted in the field and lab, including L. Barber, H. Crossman, A. DeBusschere, H. Konschuh, M. MacDonald, A. Mackay, and A. Mycock. Thanks also to R. Lemke for his helpful comments on an earlier version of this manuscript.

Open Access This article is distributed under the terms of the Creative Commons Attribution License which permits any use, distribution, and reproduction in any medium, provided the original author(s) and the source are credited.

\section{References}

Arah JRM (1997) Apportioning nitrous oxide fluxes between nitrification and denitrification using gas-phase mass spectrometry. Soil Biol Biochem 29:1295-1299

Aulakh MS, Doran JW, Walters DT, Mosier AR, Francis DD (1991) Crop residue type and placement effects on denitrification and mineralization. Soil Sci Soc Am J 55:1020-1025

Baggs EM (2008) A review of stable isotope techniques for $\mathrm{N} 2 \mathrm{O}$ source partitioning in soils: recent progress, remaining challenges and future considerations. Rapid Commun Mass Spectrom 22:1664-1672

Baggs EM, Rees RM, Smith KA, Vinten AJA (2000) Nitrous oxide emission from soils after incorporating crop residues. Soil Use Manag 16:82-87

Beckie HJ, Brandt SA, Schoenau JJ, Campbell CA, Henry JL, Janzen HH (1997) Nitrogen contribution of field pea in annual cropping systems. 2. Total nitrogen benefit. Can J Plant Sci 77:323-331

Bedard-Haughn A, Matson AL, Pennock DJ (2006) Land use effects on gross nitrogen mineralization, nitrification, and $\mathrm{N}_{2} \mathrm{O}$ emissions in ephemeral wetlands. Soil Biol Biochem 38:3398-3406

Booth MS, Stark JM, Rastetter E (2005) Controls on nitrogen cycling in terrestrial ecosystems: a synthetic analysis of literature data. Ecol Monogr 75:139-157

Chalk PM (1998) Dynamics of biologically fixed N in legumecereal rotations: a review. Aust J Agric Res 49:303-316
Corre MD, van Kessel C, Pennock DJ (1996) Landscape and seasonal patterns of nitrous oxide emissions in a semiarid region. Soil Sci Soc Am J 60:1806-1815

Curtin D, Wang H, Selles F, McConkey BG, Campbell CA (2000) Tillage effects on carbon fluxes in continuous wheat and fallow-wheat rotations. Soil Sci Soc Am J 64:2080-2086

Davidson EA, Hart SC, Shanks CA, Firestone MK (1991) Measuring gross nitrogen mineralization, immobilization, and nitrification by $\mathrm{N}-15$ isotopic pool dilution in intact soil cores. J Soil Sci 42:335-349

Ellert BH, Janzen HH (2008) Nitrous oxide, carbon dioxide and methane emissions from irrigated cropping systems as influenced by legumes, manure and fertilizer. Can J Soil Sci 88:207-217

Environment Canada (2012) National climate data and information archive. http://www.climate.weatheroffice.ec.gc.ca/. Accessed April 2012

Gan Y, Malhi SS, Brandt S, Katepa-Mupondwad F, Kutcher HR (2007) Juncea canola in the Northern Great Plains: responses to diverse managements and nitrogen fertilization. Agron J 99:1208-1218

Gan YT, Campbell CA, Janzen HH, Lemke RL, Basnyat P, McDonald CL (2010) Nitrogen accumulation in plant tissues and roots and $\mathrm{N}$ mineralization under oilseeds, pulses, and spring wheat. Plant Soil 332:451-461

Gan YT, Liang BC, Liu LP, Wang XY, McDonald CL (2011) $\mathrm{C}: \mathrm{N}$ ratios and carbon distribution profile across rooting zones in oilseed and pulse crops. Crop Pasture Sci 62:496-503

Grant B, Smith WN, Desjardins R, Lemke R, Li C (2004) Estimated $\mathrm{N}_{2} \mathrm{O}$ and $\mathrm{CO}_{2}$ emissions as influenced by agricultural practices in Canada. Clim Change 65:315-332

Hadas A, Kautsky L, Goek M, Kara EE (2004) Rates of decomposition of plant residues and available nitrogen in soil, related to residue composition through simulation of carbon and nitrogen turnover. Soil Biol Biochem 36:255-266

Hart SC, Stark JM, Davidson EA, Firestone MK (1994) Nitrogen mineralization, immobilization, and nitrification. In: Weaver R (ed) Methods of soil analysis, Part 2. Microbiological and biochemical properties. SSSA book series, No. 5. American Society of Agronomy, Madison, WI, pp 985-1019

Hoyle FC, Murphy DV (2011) Influence of organic residues and soil incorporation on temporal measures of microbial biomass and plant available nitrogen. Plant Soil 347:53-64

Huang Y, Zou J, Zheng X, Wang Y, Xu X (2004) Nitrous oxide emissions as influenced by amendment of plant residues with different C: $\mathrm{N}$ ratios. Soil Biol Biochem 36:973-981

IPCC (2007) Contribution of Working Group I to the Fourth Assessment Report of the Intergovernmental Panel on Climate Change. Cambridge University Press, Cambridge

Janzen HH, Kucey RMN (1988) C-mineralization, N-mineralization and S-mineralization of crop residues as influenced by crop species and nutrient regime. Plant Soil 106:35-41

Johnston AM, Kutcher HR, Bailey KL (2005) Impact of crop sequence decisions in the Saskatchewan Parkland. Can J Plant Sci 85:95-102

Kaur AJ, Ross DS, Fredriksen G (2010) Effect of soil mixing on nitrification rates in soils of two deciduous forests of Vermont, USA. Plant Soil 331:289-298 
Kirkegaard JA, Howe GN, Mele PM (1999) Enhanced accumulation of mineral-N following canola. Aust J Exp Agric 39:587-593

Kirkham D, Bartholomew WV (1954) Equations for following nutrient transformation in soil, utilizing tracer data. Soil Sci Soc Am J Proc 18:33-34

Lemke RL, Izaurralde RC, Nyborg M (1998) Seasonal distribution of nitrous oxide emissions from soils in the parkland region. Soil Sci Soc Am J 62:1320-1326

Lemke RL, Goddard TG, Selles F, Zentner RP (2002) Nitrous oxide emissions from wheat-pulse rotations on the Canadian prairies. In: In 4th Canadian Pulse Research Workshop. Edmonton, AB. 8 Dec. 2002. Pulse Canada, Winnipeg, MB, pp 95-98

Lemke RL, Zhong Z, Campbell CA, Zentner R (2007) Can pulse crops play a role in mitigating greenhouse gases from north American agriculture? Agron J 99:1719-1725

Lupwayi NZ, Soon YK (2009) Nitrogen release from field pea residues and soil inorganic $\mathrm{N}$ in a pea-wheat crop rotation in northwestern Canada. Can J Plant Sci 89:239-246

Ma WK, Bedard-Haughn A, Siciliano SD, Farrell RE (2008) Relationship between nitrifier and denitrifier community composition and abundance in predicting nitrous oxide emissions from ephemeral wetland soils. Soil Biol Biochem 40:1114-1123

Madigan M, Martinko J, Stahl D, Clark DP (2010) Brock Biology of Microorganisms, 13th edn. Benjamin Cummings, San Francisco, CA

Malhi SS, Lemke R, Wang ZH, Chhabra BS (2006) Tillage, nitrogen and crop residue effects on crop yield, nutrient uptake, soil quality, and greenhouse gas emissions. Soil Tillage Res 90:171-183

Malhi SS, Brandt SA, Lemke R, Moulin AP, Zentner RP (2009) Effect of input level and crop diversity on soil nitrate-N, extractable $\mathrm{P}$, aggregation, organic $\mathrm{C}$ and $\mathrm{N}$, and nutrient balance in the Canadian Prairie. Nutr Cycl Agroecosyst $84: 1-22$

Mayer J, Buegger F, Jensen ES, Schloter M, Heß J (2003) Residual nitrogen contribution from grain legumes to succeeding wheat and rape and related microbial process. Plant Soil 255:541-554

McKenney DJ, Wang SW, Drury CF, Findlay WI (1993) Denitrification and mineralization in soil amended with legume, grass, and corn residues. Soil Sci Soc Am J 57:1013-1020

Miller PR, Holmes JA (2005) Cropping sequence effects of four broadleaf crops on four cereal crops in the Northern Great Plains. Agron J 97:189-200

Miller PR, Engel RE, Holmes JA (2006) Cropping sequence effect of pea and pea management on spring wheat in the Northern Great Plains. Agron J 98:1610-1619

Mosier AR, Halvorson AD, Reule CA, Liu XJ (2006) Net global warming potential and greenhouse gas intensity in irrigated cropping systems in Northeastern Colorado. J Environ Qual 35:1584-1598

Murphy DV, Recous S, Stockdale EA, Fillery IRP, Jensen LS, Hatch DJ, Goulding KWT (2003) Gross nitrogen fluxes in soil: theory, measurement and application of N-15 pool dilution techniques. In: Advances in Agronomy, vol 79, Advances in Agronomy, pp 69-118

Ofosu-Budu KG, Fujita K, Ogata S (1990) Excretion of ureide and other nitrogenous compounds by the root system of soybean at different growth stage. Plant Soil 128:135-142
Pennock D (2006) Towards optimum sampling for regionalscale $\mathrm{N}_{2} \mathrm{O}$ emission monitoring in Canada. Can J Soil Sci 86:441-450

Raun WR, Johnson GV (1999) Improving nitrogen use efficiency for cereal production. Agron J 91:357-363

Recous S, Aita C, Mary B (1999) In situ changes in gross N transformations in bare soil after the addition of straw. Soil Biol Biochem 31:119-133

Robinson D (2001) $\delta^{15} \mathrm{~N}$ as an integrator of the nitrogen cycle. Trends Ecol Evol 16:153-162

Rochette P, McGinn S (2008) $\mathrm{N}_{2} \mathrm{O}$ emissions from agricultural soils in Canada-Preface. Can J Soil Sci 88:131-132

Russow R, Spott O, Stange CF (2008) Evaluation of nitrate and ammonium as sources of $\mathrm{NO}$ and $\mathrm{N}_{2} \mathrm{O}$ emissions from black earth soils (Haplic Chernozem) based on N-15 field experiments. Soil Biol Biochem 40:380-391

Rutting T, Boeckx P, Muller C, Klemedtsson L (2011) Assessment of the importance of dissimilatory nitrate reduction to ammonium for the terrestrial nitrogen cycle. Biogeosciences 8:1779-1791

Ryan MH, Kirkegaard JA, Angus JF (2006) Brassica crops stimulate soil mineral N accumulation. Aust J Soil Res 44:367-377

Saetre P, Stark JM (2005) Microbial dynamics and carbon and nitrogen cycling following re-wetting of soils beneath two semi-arid plant species. Oecologia 142:247-260

Sangster A, Knight D, Farrell R, Bedard-Haughn A (2010) Repeat-pulse $\left(\mathrm{CO}_{2}\right)-\mathrm{C}-13$ labeling of canola and field pea: implications for soil organic matter studies. Rapid Commun Mass Spectrom 24:2791-2798

Schimel JP, Bennett J (2004) Nitrogen mineralization: challenges of a changing paradigm. Ecology 85:591-602

Schmidt CS, Richardson DJ, Baggs EM (2011) Constraining the conditions conducive to dissimilatory nitrate reduction to ammonium in temperate arable soils. Soil Biol Biochem 43:1607-1611

Shah Z, Ahmad SR, Rahman HU (2010) Soil microbial biomass and activities as influenced by green manure legumes and $\mathrm{N}$ fertilizer in rice-wheat system. Pak J Bot 42:2589-2598

Shelp ML, Beauchamp EG, Thurtell GW (2000) Nitrous oxide emissions from soil amended with glucose, alfalfa, or corn residues. Commun Soil Sci Plant Anal 31:877-892

Soon YK, Arshad MA (2004) Contribution of di-nitrogen fixation by pea to the productivity and $\mathrm{N}$ budget of a wheatbased cropping system. J Agric Sci 142:629-637

Sørensen P, Jensen ES (1991) Sequential diffusion of ammonium and nitrate from soil extracts to a polytetrafluoroethylene trap for ${ }^{15} \mathrm{~N}$ determination. Anal Chim Acta 252:201-203

Stark JM, Hart SC (1996) Diffusion technique for preparing salt solutions, Kjeldahl digests, and persulfate digests for nitrogen-15 analysis. Soil Sci Soc Am J 60:1846-1855

Statistics Canada (2006) Census of Agriculture. http://www40. statcan.ca/101/cst01/agrc25f.htm. Accessed September 15

Stevenson FC, van Kessel C (1996) The nitrogen and non nitrogen benefits of pea to succeeding crops. Can J Plant Sci 76:735-745

Tanaka DL, Krupinsky JM, Merrill SD, Liebig MA, Hanson JD (2007) Dynamic cropping systems for sustainable crop production in the Northern Great Plains. Agron J 99:904-911 
Walley FL, Clayton GW, Miller PR, Carr PM, Lafond GP (2007) Nitrogen economy of pulse crop production in the Northern Great Plains. Agron J 99:1710-1718

Wan YJ, Ju XT, Ingwersen J, Schwarz U, Stange CF, Zhang FS, Streck T (2009) Gross nitrogen transformations and related nitrous oxide emissions in an intensively used calcareous soil. Soil Sci Soc Am J 73:102-112

Wichern F, Eberhardt E, Mayer J, Joergensen RG, Muller T (2008) Nitrogen rhizodeposition in agricultural crops: methods, estimates and future prospects. Soil Biol Biochem 40:30-48
Wrage N, Velthof GL, van Beusichem ML, Oenema O (2001) Role of nitrifier denitrification in the production of nitrous oxide. Soil Biol Biochem 33:1723-1732

Yates TT, Si BC, Farrell RE, Pennock DJ (2006) Probability distribution and spatial dependence of nitrous oxide emission: temporal change in hummocky terrain. Soil Sci Soc Am J 70:753-762

Zhang JB, Zhu TB, Cai ZC, Qin SW, Muller C (2012) Effects of long-term repeated mineral and organic fertilizer applications on soil nitrogen transformations. Eur J Soil Sci 63:75-85 